\title{
The Effects of Work Stress on Employees Performance in the Banking Sector of Cameroon: Case of NFC Bank PLC Cameroon
}

\author{
Tabi Felicia Banyi \\ ICT University, Cameroon \\ E-mail: tabifelicia.banyi@ictuniversity.org \\ Ndah Grimbald (Corresponding author) \\ ICT University, Cameroon \\ E-mail: ndah.grimbald@ictuniversity.org
}

Dr. Wuchu Cornelius Wutofeh

ICT University, Cameroon

E-mail: Wuchucornelius.wutofeh@ictuniversity.org

\author{
Henry Jong Ketuma \\ ICT University, Cameroon \\ E-mail: henryketuma@gmail.com
}

Received: November 24, 2021 Accepted: February 19, 2021 Published: February 23, 2021

doi:10.5296/ber.v11i1.17980

URL: https://doi.org/10.5296/ber.v11i1.17980

\begin{abstract}
The overall issue of stress management in National Financial Credit (NFC) Bank in Cameroon is so essential that it plays a critical role in ascertaining and ensuring a stress free financial services industry. It is the ultimate dream of every employer to have a stress free job environment. Thus having the right attitude to execute the job in order to increase productivity has not always been the case. The purpose of this study was to establish the
\end{abstract}


relationship between the effects of work stress and job performance in the Cameroonian banking sector. Specifically, the study sought to explore the views of employees at National Financial Credit Bank regarding the issue of stress, its impact on employee performance and its management. Descriptive survey design was adopted as the most appropriate design for the study. The purposive and convenient sampling techniques were used to select all the heads of departments in the bank and the other bank employees for the study respectively. A sample of 50 respondents participated in the study. A questionnaire was designed based on a five point-likert Scale used in data collection. Five causal relationships were hypothesized and findings show that there was significant and positive correlation between employee performance and Work stress. Organizational level stress and group level stress as a mediating variable between individual level stress and work performance have a positive statistical significant effect on the performance of workers. This can be seen in table 13 (harmonized test of hypotheses) where the P_value for the stated hypotheses are significant within a 99\% confidence interval level. The limitation of this study is that it was purely a quantitative based study. Future research should focus on using qualitative approaches to give an in-depth understanding on the causes of stress, the effects of stress and how stress management strategies can be designed to work. This study can offer useful information and insights for clarifying certain corporate concepts and can help to shape the development of future theory as well as the procedure for data collection and testing.

Keywords: Job stress, Role conflict, Role ambiguity, Work overload, Time pressures, Lack of creativity and motivation

\section{Introduction}

Lately, there have been so many academic articles written regarding job related stress to the extent that one can come to conclusion that, everyone everywhere especially within a job setting is depressed and demoralized. With the existence of stress in almost all organizations, management is uncertain to take up appropriate measures to address them. According to Dyck (2015), an employee quality of life can be affected by a couple of job stress factors which can make an assigned task difficult and stressful for the employee to accomplish no matter the environment. In the field of business and management studies, workplace stress has taken center stage in research as the costs to organizations and employees is very high (Arshadi and Damiri, 2013; Webster et al., 2010). Farler and Broady-Preston (2012) suggested that a work-place is a community of its own; hence employees derive their sense of identity and belongingness from it. Stress in the workplace would therefore affect employees significantly and ultimately the performance of the entire organization would also be at stake (Ahmad Ezane et al., 2012). The commonly cited implications of work-place stress include low job performance and high turnover intention (Arshadi and Damiri, 2013), lack of motivation and ill health (Farler and Broady-Preston, 2012) as well as burnout (Ahmad Ezane et al., 2012). Keshavarz and Mohammadi (2011) added low morale, poor product quality, low output, increased over-time payment, and organizational sabotage to the list of negative effects of workplace stress.

Work stress is defined as the perception of a difference between environmental demands 


\section{Macrothink}

(stressors) and individual capacities to fill these demands (Kleiner, 2015). Christo and Pienaar (2014) for example, assert that the causes of work stress include perceived loss of job and/or job insecurity, sitting for long periods of time or heavy lifting, lack of safety, complexity of repetitiveness and lack of autonomy in the job. More still, work stress is caused by lack of resources and equipment; work schedules such as working late or overtime and organizational climate are considered as contributors to employees stress. work stress often shows high dissatisfaction among the employees, job mobility, burnout, poor work performance and less effective interpersonal relations at work (Chong, 2010). The reason why Work stress has been receiving so much concern lately is that organizations are actually beginning to care about the welfare of employee. It is estimated by the International Labour Organization that stress on the job costs business in Europe over \$200 billion per year. These include salaries for sick days, hospitalization fee and outpatient care and costs related to decreased performance. The purpose of this study therefore, is to establish the relationship between the effects of work stress and job performance in the Cameroonian banking sector.

\section{Literature Survey}

Worker stress is defined as the interaction between the person and the sources of stress within their workplace, it become stress when demand exceeds from resources (Long, 2015). From previous researchers found that work stress arises when demand that exceeds on her/his and physiological balance. Cox, Dewe and Ferguson (2003) stated that stress is not totally internal attitude of individual or his environment but it is the interaction between them, also can call as ongoing transaction, the relationship of person and surrounding. In every organization and all level of workers an average level of stress is to find which mostly give effect on employee's job performance. Employees have potency towards high level of stress regarding working hour, longer hours which reduce employees urge to perform (Rose, 2013).

\subsection{Stressors in the Workplace}

A stressor can be defined as environmental factors that produce stress (Krietner and Kinicki, 2008). A model of Work stress developed by Krietner and Kinicki (2008) highlighted stress on four levels and their outcomes based on the coping strategy chosen to manage such stressors (Figure 1). 


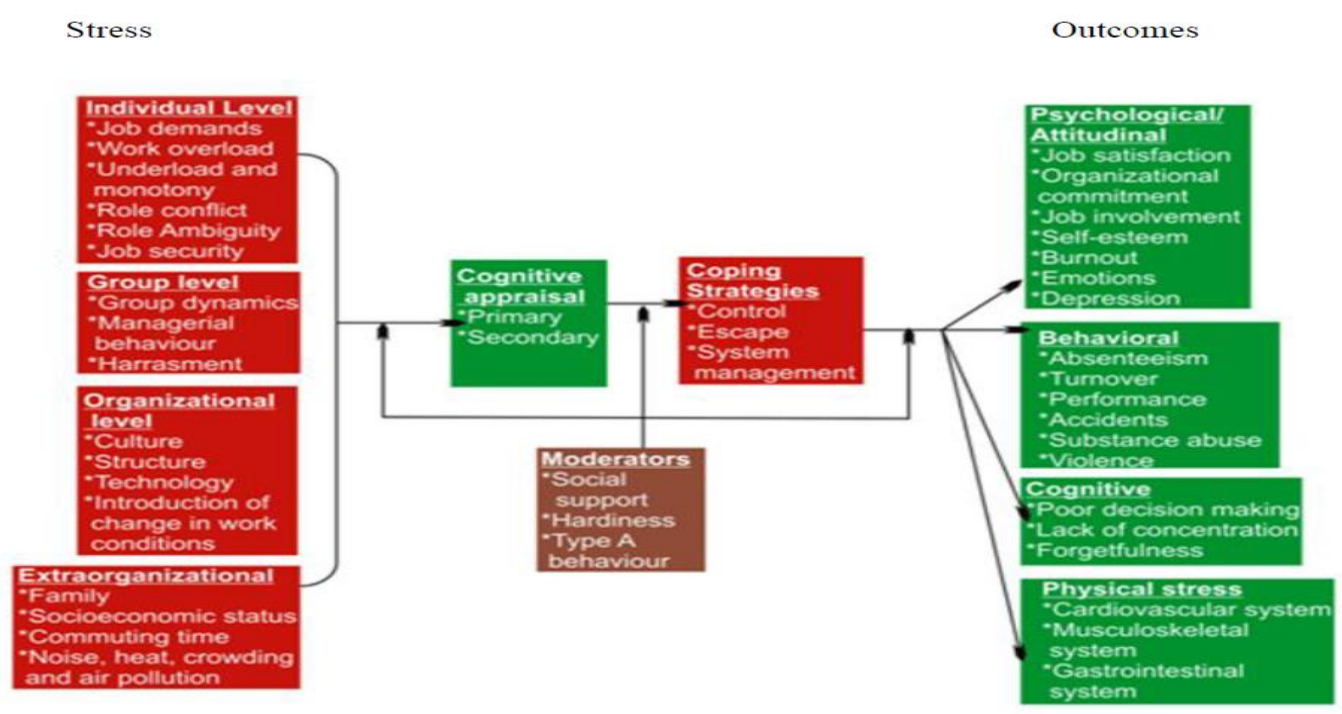

Figure 1. A model of work Stress adapted from Krietner and Kinicki (2008), Organizational Behaviour 8th Edition, McGraw Hill Publishing, New York

The model identified four levels of stress; individual level stress, group level stress, organizational level stress and extra-organizational level stress which in turn could lead to stress which can result in psychological/attitudinal, behavioral, cognitive and physical stress disorders, as identified in each of the categories. However, when assessing the model it is likely that there could be a combination of stressors as well as coping strategies that can be employed which could lead to a combination of outcomes, thereby ensuring that each is not mutually exclusive and only occurs in isolation.

\subsection{Financial and Economic Impact of Stress on Organizations}

The financial and economic impact of workplace stress cannot be ignored. It is generally accepted that untreated workplace stress is associated with increased levels of employee absenteeism and turnover, decreased levels of productivity as well as lost workdays due to disability or sick leave (Williams, 2013). According to Greenberg and Baron (2005) the negative effects of stress included reduced efficiency, decreased capacity to perform dampened initiative and reduced interest in working, increased rigidity of thought, a lack of concern for the organization and colleagues, and a lack of responsibility.

According to a study conducted by the American Institute of Stress in 2008, an estimated one million people miss work daily as a result of stress. According to the Institute, the annual tab for all these lost hours due to absenteeism; reduced productivity; turnover; and medical, legal, and insurance costs comes to $\$ 300$ billion or $\$ 7,500$ per worker (Kreitner and Kinicki, 2016). In addition, the number of legal cases against employers related to employees experiencing work stress has been on the increase. In the first case in the banking industry, a former Lloyds Bank employee was awarded more than $£ 100,000$ in an out of court settlement after claiming to be suffering from post-traumatic stress when he was put under intolerable pressure to meet 
increasing sales targets (Blaug, et all, 2007).

\subsection{Theoretical Review}

Theories help us to understand underlying process and on that basis, choose an effective course of action. According to Stoner and Freeman (2010), a theory is a coherent group of assumption put forth to explain the relationship between two or more observable facts. Valid theories enable us to predict what will happen under certain situations. It is a truism that no matter the degree of the grasp of a principle, the history and theories of any field help us to apply them to actual cases. The theories relevant in the study of work stress and its effects on job performance include the following; stimulus-based, interactional, person environment fit, role overload and role theory.

\subsubsection{Theoretical Approaches to Stress}

There are a wide variety of various definitions and theories pertaining to the dynamic construct of stress. In an attempt to organize all of these theories Ghadially and Kumar 2007) suggested that there were at least three distinct orientations, which were (a) stimulus-based, (b) response literature supports the idea that there are three different theoretical approaches to the concept of stress (Richard and Krieshok, 2009; Ryan, 2007; Trivette, 2006).

\subsubsection{Stimulus-Based Theory}

Kahn (2006) defines stimulus-based stress as external forces or conditions that are hypothesized or demonstrated to have negative (painfully damaging, incapacitating) effects on the organization of interest. Stimulus-based stress theorists believe that the factors in the environment exert an influence on an individual (Derogatis and coans, 2003; Larzarus and Folk man, 2006, Meichenbaum, 2006). Essentially this model proposes that external stressors in the environment result in a stress reaction or stain (Cox, 2005). In addition, different categories of stimulus stressors have been identified in terms of their ability to induce stress such as: (a) acute, time-limited stressors; (b) Chronic intermittent stressors; (c) stressors sequences; and (d) chronic stressors; (Derogatis and Coons, 2009).

\subsubsection{Interactional Theory}

The interactional approach to stress incorporates both stimulus-based and response based approaches (Cox, 2005; Richard and Krieshok, 2004). This theory has also been referred to as the stimulus-response interaction (Greenberg, 2008). The interactional approach stipulates that situational variable interact with personal variable from which stress result (Ryan, 2006). Current research supports the theoretical construct set forth by the interactional approach. Fogerty et al. (2009) conducted four separate studies which analyzed work stress, strain and coping through path analysis. Decker and Borgon (2003) also advocated for an intersectional approach for researchers interested in studying variables related to work stress, strain, and coping because they feel it -fully examines the individual's unique psychological experience of work.

Cox and Mckay (2006) took the interactional approach to stress one step further and have proposed that there is another to this approach (Cox, 2005). This theory has been referred to 
as transactional (Greenbery, 2009). The Transactional approach incorporates the stimulus, response, cognitive appraisal of the stressors, coping style of the individual psychological defenses, and social milieu into account (Folkman and Lazarus, 2008).

\subsubsection{Role Theory}

In order to fulfill expected service - over the last decade human service, agencies, in most western economies have undergone major organizational restructuring and redefinitions of professional rules(Biggs et al; 2005). One of the basic premises of the role theory is that various work roles that individuals engage in may be stressful regardless of their actual occupation, suggesting that stress found in various work roles may be stressful for all workers. Osipow and Spokane (2007) described six work roles that they felt were stressful regardless of an individual's actual vocational choice. These six roles are (a) role ambiguity (b) role insufficiency (c) role overload (d) role boundary (e) responsibility and (f) physical environment (Osipow \& Spokane, 2007; Osipow, 2008).

\subsubsection{Person-Environment Fit Theory}

A review of the literature suggests that researchers have attempted to find an explanation regarding the potential relationship that exists between stress, an individual, and the environment. It has been theorized that if there is not an accurate fit between the person and the environment, strain will occur (French, Captan, and Harrison, 1982). More specifically, a person environment fit suggests that individual fit certain occupations based on the interaction of a multitude of variables. Theoretically, P-E Fit — predicts that the magnitude of strain experienced by an individual is proportional to the degree of misfit between the individual and their occupation (Pithess and Soden, 2009).Individuals — vary in their needs and abilities just as jobs vary in their incentives and demands (French et al.; 2006).

\subsubsection{Role Overload Theory}

Role Overload (RO) measures the extent to which job demands exceed resources (personal and workplace) and the extent to which the individual is able to accomplish workloads (Osipow, 2008). Role overload can result in an employee -experiencing anger and frustration toward persons believed responsible for the overload in work (Marini et al; 2010). Decker and Borgen (2007) found that Role Overload for University of California workers was modestly correlated with stress. Trivette (2012) found that Role Overload scores for tertiary education workers were in the average range for both genders. However, Trivette (2013) found that lectures who worked at two or more schools had higher stress level. In addition working at two or more school settings was significantly correlated with higher Role Overload scores in comparison to one school. Aitken and Schloss (2014) found that for banking staff working with, Role Overload was reported to be high due to the Physical environment.

\subsection{Relationship between Work Stress and Employee Performance}

In most work and job situations, stress responses cause performance to suffer. A calm, rational, controlled and sensitive approach is usually called for in dealing with most difficult 


\section{Macrothink}

problems at work: Our social inter-relationships are just too complex not to be damaged by an aggressive approach, while a passive and withdrawn response to stress means that we can fail to assert our rights when we should (Mokdad, 2005). The relationship between stress and employee performance is explained in one of the oldest and most important ideas in stress management, the "Inverted-U" relationship between pressure and performance. The Inverted-U relationship focuses on people's performance of a task.

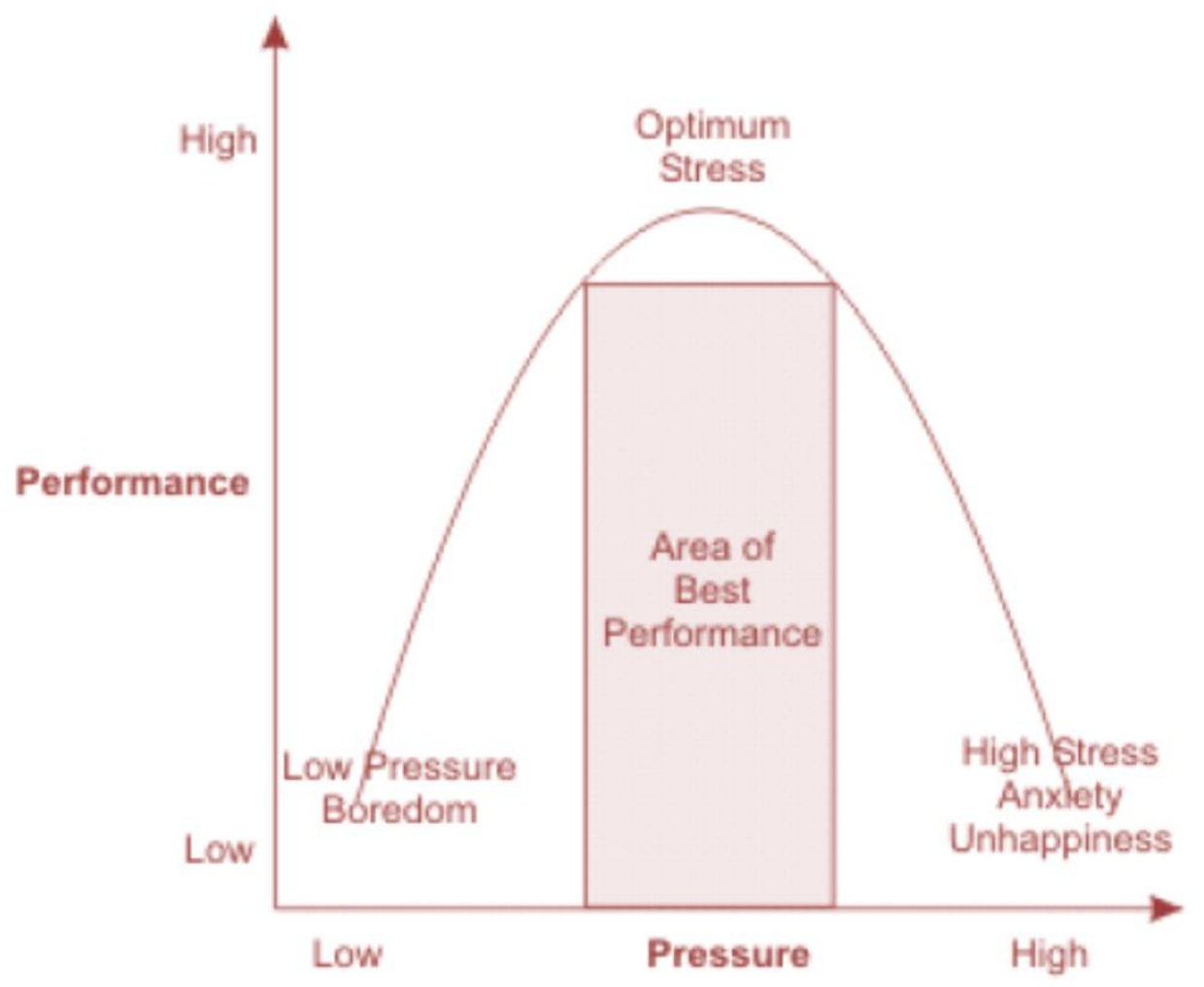

The Inverted-U relationship between pressure and performance

Figure 2. The Inverted-U relationship between pressure and performance

Source: Gillespie et al., 2015

The left hand side of the graph indicates that when there is very little pressure on us to carry out an important task, there is little incentive for employees to focus energy and attention on it. This is particularly the case when there may be other, more urgent, or more interesting, tasks competing for attention. As pressure on employees' increases, they enter the "area of best performance". Here, they are able to focus on the task and perform well - there is enough pressure on employees to focus their attention but not so much that it disrupts their performance. As employees become uncomfortably stressed; distractions, difficulties, anxieties and negative thinking begin to crowd their minds. This is particularly the case where the definition of stress comes in, i.e. that it occurs when a person perceives that "demands exceed the personal and social resources the individual is able to mobilize." These 
thoughts compete with performance of the task for employee's intentional capacity and therefore, concentration suffers, and focus narrows as their brains become overloaded. As shown in the figure, this is something of a slippery slope: the more the brain is overloaded, the more employees' performance can suffer. The more their performance suffers, the more new distractions, difficulties, anxieties and negative thoughts crowd their minds.

\subsection{Hypotheses Statement}

The Krietner \& Kinicki (2008) model highlighted stress on four levels and their outcomes based on the coping strategy chosen to manage such stressors. The following assumptions were made based on the above model in order to achieve the purpose of this study;

H1: Individual level stress has a significant effect on the work performance of NFC Bank Staff.

H2: Group level stress has a significant effect on the work performance of NFC Bank staff.

H3: Organizational level stress has a significant effect on the work performance of NFC Bank Staff.

H4: Extra organizational level stress has a significant effect on the performance of NFC Bank Staff.

H5: Group level Stress has a significant positive mediating impact on the relationship between Individual level stress and the work performance of NFC Bank Staff.

\section{Methodology}

The reality under study is the impact work stress has on the performance of workers in the financial services industry in Cameroon with particular emphasis on National Financial credit (NFC) bank. The phenomenon under study is objectively ascertained and the source of acceptable knowledge is positivism epistemology (Akosso, Isoh \& Ndah, 2020). The research approach is deductive and the axiological underpinning is value-free. This study made use of the descriptive survey research design and adopted the survey strategy as the best approach to provide answers to the research questions and achieve the research objectives. It enabled the researchers to ascertain respondents' perceptions on the current practices for easy description of the situation and to make intelligent recommendations to improve the situation. The researchers sought to establish a relationship between the effects of work stress and the performance of employees in the banking sector. Data are quantitatively analysed using Statistical inferences and modeling with the use of statistical software's like SPSS and AMOS. The study applied both the purposive and convenient sampling techniques in selecting the heads of department and other senior employees' respectively. A sample of 50 respondents participated in the study. Research questions were administered with the use of questionnaires because it has the ability to harness data from a large sample that may be geographically dispersed, and provides broad statistical analysis options(Zikmund, 2003). Well-structured questionnaires were used in this study to provide a hypothetical response of 50 respondents on SPSS worksheet using a 5 Likert scale (SA-SD) and Mean as the measurement of central tendency. 


\section{1) Macrothink}

\section{Data Analysis and Presentation of Results}

\subsection{Exploratory Factor Analysis for the Dependent Latent Construct}

Data cleaning and management was done and completed using Exploratory Factor Analysis (EFA) for the dependent latent construct which is employee productivity (EPT). The different modalities for analysis were checked. First of all, the discriminant for the correlation of 4 items observed in the construct represents a coefficient of 0.258 which is greater than the threshold of 0.01 indicating that there is no evidence of multi-collinearity in the data set as shown below;

Table 1. Correlation Matrix ${ }^{\mathrm{a}}$

\begin{tabular}{|l|l|l|l|l|l|l|}
\hline \multicolumn{2}{|c|}{} & EPT1 & EPT2 & EPT3 & EPT4 & EPT5 \\
\hline Correlation & EPT1 & 1.000 & .454 & .262 & .301 & .558 \\
\cline { 2 - 7 } & EPT2 & .454 & 1.000 & .323 & .442 & .366 \\
\cline { 2 - 7 } & EPT3 & .262 & .323 & 1.000 & .508 & .109 \\
\cline { 2 - 7 } & EPT4 & .301 & .442 & .508 & 1.000 & .441 \\
\cline { 2 - 7 } & EPT5 & .558 & .366 & .109 & .441 & 1.000 \\
\hline \multirow{5}{*}{ Sig. (1-tailed) } & EPT1 & & .000 & .033 & .017 & .000 \\
\cline { 2 - 7 } & EPT2 & .000 & & .011 & .001 & .004 \\
\cline { 2 - 7 } & EPT3 & .033 & .011 & & .000 & .226 \\
\cline { 2 - 7 } & EPT4 & .017 & .001 & .000 & & .001 \\
\cline { 2 - 7 } & EPT5 & .000 & .004 & .226 & .001 & \\
\hline a. Determinant & $=.258$ & & & \\
\hline
\end{tabular}

Source: SPSS Output

In addition, the Kaiser-Meyer-Olkin measure of sampling adequacy $(\mathrm{KMO}=0.638>0.5)$ and the Bartlett's Test of Sphericity with Approx. Chi-Square $(\mathrm{X} 2=63.071)$, Degree of Freedom $(\mathrm{DF}=10)$ and $\mathrm{P}$-Value (sig $=0.00<0.05)$ both revealed adequacy of the sample size and the existence of at least 1 significant correlation in the data set as shown in the table below.

Table 2. KMO and Bartlett's Test

\begin{tabular}{|l|l|l|}
\hline \multicolumn{2}{|l|}{ Kaiser-Meyer-Olkin Measure of Sampling Adequacy. } & .638 \\
\hline Bartlett's Test of Sphericity & Approx. Chi-Square & 63.071 \\
\cline { 2 - 3 } & df & 10 \\
\cline { 2 - 3 } & Sig. & .000 \\
\hline
\end{tabular}

Source: SPSS Output

Also, the factors involved in the analysis were extracted using principal component analysis based on Eigen value of 1 and using Varimax rotation revealed the following results: Four new components were extracted but only component 1 and component 2 have Eigen values of 


\section{Ml Macrothink}

Business and Economic Research ISSN 2162-4860 2021, Vol. 11, No. 1

2.520 and 1.010 respectively which is more than the threshold of 1 and a cumulative extracted variance of $70.600 \%$ whereas, component three, four and five have Eigen values of $0.619 \%, 0.558 \%$ and $0.293 \%$ which are all less than the minimum threshold of 1 ; thus rejected as shown on the table below;

Table 3. Total Variance Explained

\begin{tabular}{|l|l|l|l|l|l|l|}
\hline \multirow{2}{*}{ Component } & \multicolumn{3}{|l|}{ Initial Eigenvalues } & \multicolumn{3}{l|}{ Extraction Sums of Squared Loadings } \\
\cline { 2 - 7 } & Total & \% of Variance & Cumulative \% & Total & \% of Variance & Cumulative \% \\
\hline 1 & 2.520 & 50.398 & 50.398 & 2.520 & 50.398 & 50.398 \\
\hline 2 & 1.010 & 20.202 & 70.600 & & & \\
\hline 3 & .619 & 12.374 & 82.974 & & & \\
\hline 4 & .558 & 11.167 & 94.141 & & & \\
\hline 5 & .293 & 5.859 & & & \\
\hline
\end{tabular}

Source: SPSS Output

The component matrix obtained explains the factor loadings for the respective components observed in the analysis. However, only indicators in component 1 with an extracted variance of $50.398 \%$ will be considered in this study because it has the highest $\%$ of variance extracted. In the analysis, the retained as well as rejected indicators are shown on the component matrix table below.

Table 4. Rotated Component Matrix ${ }^{\mathrm{a}}$

\begin{tabular}{|l|l|l|}
\hline \multirow{2}{*}{} & \multicolumn{2}{|l|}{ Component } \\
\cline { 2 - 3 } & 1 & 2 \\
\hline EPT1 & .821 & \\
\hline EPT2 & .563 & .908 \\
\hline EPT3 & & .750 \\
\hline EPT4 & .871 & \\
\hline EPT5 & \multicolumn{2}{|l|}{} \\
\hline Extraction Method: Principal Component Analysis. \\
Rotation Method: Varimax with Kaiser Normalization. \\
\hline \multicolumn{2}{|l}{ a. Rotation converged in 3 iterations. } \\
\hline
\end{tabular}

Based on the analysis above, retained and rejected indicators for the dependent latent construct were illustrated. The indicators in component 1 are those that are retained in this study while indicators in component two are those that were rejected.

\subsection{Exploratory Factor Analysis for Independent Latent Constructs}

The independent latent constructs in the model consist of individual level stress (ILS), group level stress (GLS), Organizational level stress (OLS), and extra-organizational level stress (ELT), The specifications for the analysis of exploratory factor analysis were conducted. The 
correlation matrix showing the interconnectivity amongst indicators revealed a discriminant coefficient of $0.11>0.1$ showing that the assumption of multi-collinearity is admissible implying questions were unique and did not explain each other.

Table 5. Correlation Matrix

\begin{tabular}{|c|c|c|c|c|c|c|c|c|c|c|c|c|}
\hline & & ILS1 & ILS2 & GLS1 & GLS2 & GLS3 & OLS1 & OLS2 & OLS3 & ELS4 & ELS5 & ELS6 \\
\hline \multirow[t]{11}{*}{ Correlation } & ILS1 & 1.000 & .700 & .341 & .266 & .303 & .233 & .286 & .184 & .004 & .032 & .201 \\
\hline & ILS2 & .700 & 1.000 & .359 & .289 & .171 & .220 & .279 & .061 & -.024 & .057 & .107 \\
\hline & GLS1 & .341 & .359 & 1.000 & .584 & .624 & -.190 & -.139 & -.179 & -.037 & .017 & .415 \\
\hline & GLS2 & .266 & .289 & .584 & 1.000 & .532 & -.193 & .136 & -.093 & -.099 & -.041 & -.061 \\
\hline & GLS3 & .303 & .171 & .624 & .532 & 1.000 & -.143 & -.034 & -.169 & -.144 & .039 & .126 \\
\hline & OLS1 & .233 & .220 & -.190 & -.193 & -.143 & 1.000 & .675 & .507 & .245 & .285 & .063 \\
\hline & OLS2 & .286 & .279 & -.139 & .136 & -.034 & .675 & 1.000 & .624 & .353 & .278 & -.126 \\
\hline & OLS3 & .184 & .061 & -.179 & -.093 & -.169 & .507 & .624 & 1.000 & .299 & .243 & -.082 \\
\hline & ELS4 & .004 & -.024 & -.037 & -.099 & -.144 & .245 & .353 & .299 & 1.000 & .498 & .161 \\
\hline & ELS5 & .032 & .057 & .017 & -.041 & .039 & .285 & .278 & .243 & .498 & 1.000 & .195 \\
\hline & ELS6 & .201 & .107 & .415 & -.061 & .126 & .063 & -.126 & -.082 & .161 & .195 & 1.000 \\
\hline \multirow[t]{11}{*}{ Sig. (1-tailed) } & ILS1 & & .000 & .008 & .031 & .016 & .052 & .022 & .100 & .489 & .412 & .080 \\
\hline & ILS2 & .000 & & .005 & .021 & .117 & .062 & .025 & .337 & .435 & .346 & .229 \\
\hline & GLS1 & .008 & .005 & & .000 & .000 & .093 & .168 & .107 & .400 & .454 & .001 \\
\hline & GLS2 & .031 & .021 & .000 & & .000 & .090 & .173 & .261 & .247 & .388 & .336 \\
\hline & GLS3 & .016 & .117 & .000 & .000 & & .160 & .407 & .120 & .159 & .395 & .192 \\
\hline & OLS1 & .052 & .062 & .093 & .090 & .160 & & .000 & .000 & .043 & .023 & .332 \\
\hline & OLS2 & .022 & .025 & .168 & .173 & .407 & .000 & & .000 & .006 & .025 & .191 \\
\hline & OLS3 & .100 & .337 & .107 & .261 & .120 & .000 & .000 & & .017 & .045 & .286 \\
\hline & ELS 4 & .489 & .435 & .400 & .247 & .159 & .043 & .006 & .017 & & .000 & .132 \\
\hline & ELS5 & .412 & .346 & .454 & .388 & .395 & .023 & .025 & .045 & .000 & & .087 \\
\hline & ELS6 & .080 & .229 & .001 & .336 & .192 & .332 & .191 & .286 & .132 & .087 & \\
\hline
\end{tabular}

Source: SPSS Output

The assumptions of sampling adequacy and inter-correlation were also tested. The Kaiser-Meyer-Olkin measure of sampling adequacy $(\mathrm{KMO}=0.597>0.5)$ and the Bartlett's Test of Sphericity with Approx. Chi-Square (X2 = 208.525), Degree of Freedom $(\mathrm{DF}=55)$ and P-Value ( sig $=0.00<0.05$ ) both revealed adequacy of the sample size and the existence of at least 1 significant correlation in the data set as shown in the table below.

Table 6. KMO and Bartlett's Test

\begin{tabular}{|l|l|r|}
\hline \multicolumn{2}{|l|}{ Kaiser-Meyer-Olkin Measure of Sampling Adequacy. } & .597 \\
\hline Bartlett's Test of Sphericity & Approx. Chi-Square & 208.525 \\
\cline { 2 - 3 } & df & 55 \\
\cline { 2 - 3 } & Sig. & .000 \\
\hline
\end{tabular}

In addition, new components were extracted based on Eigen value of at least 1. Four components were extracted with Eigen value of 2.844, 2.780, 1.434 and 1.107 respectively. The total variance extracted was $74.227 \%$ constituting $25.853,25.272,13.035$ and 10.066 for component 1,2, 3 and 4 respectively. These statistics are shown below; 


\section{Macrothink}

Business and Economic Research ISSN 2162-4860 2021, Vol. 11, No. 1

Table 7. Total Variance Explained

\begin{tabular}{|c|c|c|c|c|c|c|c|c|c|}
\hline \multirow[t]{2}{*}{ Component } & \multicolumn{3}{|c|}{ Initial Eigenvalues } & \multicolumn{3}{|c|}{$\begin{array}{l}\text { Extraction Sums } \\
\text { of Squared Loadings }\end{array}$} & \multicolumn{3}{|c|}{$\begin{array}{l}\text { Rotation Sums of } \\
\text { Squared Loadings }\end{array}$} \\
\hline & Total & $\begin{array}{l}\% \text { of } \\
\text { Variance }\end{array}$ & $\begin{array}{l}\text { Cumulative } \\
\%\end{array}$ & Total & $\begin{array}{l}\% \text { of } \\
\text { Variance }\end{array}$ & $\begin{array}{l}\text { Cumulative } \\
\%\end{array}$ & Total & $\begin{array}{l}\% \text { of } \\
\text { Variance }\end{array}$ & $\begin{array}{l}\text { Cumulative } \\
\%\end{array}$ \\
\hline 1 & 2.844 & 25.853 & 25.853 & 2.844 & 25.853 & 25.853 & 2.406 & 21.872 & 21.872 \\
\hline 2 & 2.780 & 25.272 & 51.126 & 2.780 & 25.272 & 51.126 & 2.151 & 19.558 & 41.430 \\
\hline 3 & 1.434 & 13.035 & 64.161 & 1.434 & 13.035 & 64.161 & 1.916 & 17.418 & 58.848 \\
\hline 4 & 1.107 & 10.066 & 74.227 & 1.107 & 10.066 & 74.227 & 1.692 & 15.378 & 74.227 \\
\hline 5 & .707 & 6.428 & 80.654 & & & & & & \\
\hline 6 & .582 & 5.293 & 85.947 & & & & & & \\
\hline 7 & .474 & 4.305 & 90.252 & & & & & & \\
\hline 8 & .421 & 3.828 & 94.080 & & & & & & \\
\hline 9 & .296 & 2.694 & 96.775 & & & & & & \\
\hline 10 & .213 & 1.936 & 98.710 & & & & & & \\
\hline 11 & .142 & 1.290 & 100.000 & & & & & & \\
\hline
\end{tabular}

Source: SPSS Output

Furthermore, exploratory factor analysis (EFA) was conducted. Four fixed components were rotated using Varimax and the rotated component matrix below showed evidence of appropriate loading of factors for respective components with no cross loading and factor coefficient being less than 0.5. The extracted and well loaded indicators for each variable then became the retained indicator for the study as shown in the EFA table below:

Table 8. Rotated Component Matrix ${ }^{\mathrm{a}}$

\begin{tabular}{|l|c|c|c|c|}
\hline \multirow{2}{*}{} & \multicolumn{4}{|c|}{ Component } \\
\cline { 2 - 5 } & 1 & 2 & 3 & 4 \\
\hline ILS1 & & & .830 & \\
\hline ILS2 & & & .808 & \\
\hline GLS1 & & .719 & & \\
\hline GLS2 & & .885 & & \\
\hline GLS3 & & .805 & & \\
\hline OLS1 & .678 & & & \\
\hline OLS2 & .888 & & & \\
\hline OLS3 & .759 & & & \\
\hline ELS4 & & & & .739 \\
\hline ELS5 & & & & .763 \\
\hline ELS6 & \multicolumn{5}{|l|}{} \\
\hline $\begin{array}{l}\text { Extraction Method: Principal Component Analysis. } \\
\text { Rotation Method: Varimax with Kaiser Normalization. }\end{array}$ \\
\hline \multicolumn{5}{|l}{ Rotation converged in 7 iterations. } \\
\hline
\end{tabular}

In the final analysis, the table shows the retained and rejected indicators for the four independent latent constructs used in this study. 


\section{Macrothink}

Table 9. Retained and Rejected Indicators

\begin{tabular}{|c|c|c|}
\hline Codes & Retained & Rejected \\
\hline \multirow{4}{*}{ ILS } & ILS1 & ILS3 \\
\cline { 2 - 3 } & ILS2 & ILS4 \\
\cline { 2 - 3 } & & ILS5 \\
\hline \multirow{4}{*}{ GLS } & GLS1 & GLS4 \\
\cline { 2 - 3 } & GLS2 & \\
\cline { 2 - 3 } & GLS3 & \\
\hline OLS & OLS1 & OLS4 \\
\cline { 2 - 3 } & OLS2 & \\
\cline { 2 - 3 } & OLS3 & \\
\hline ELS & ELS4 & ELS1 \\
\cline { 2 - 3 } & ELS5 & ELS2 \\
\cline { 2 - 3 } & ELS6 & ELS3 \\
\hline
\end{tabular}

\subsection{Confirmatory Factor Analysis}

Furthermore, in addition to the EFA, a Confirmatory Factor Analysis (CFA) model was completed based on: GFI, CFI, IFI, TLI, RMSEA, SRMR and the Chi-Square goodness of fit parameters. All observed regression paths in the model as shown below are statistically significant.

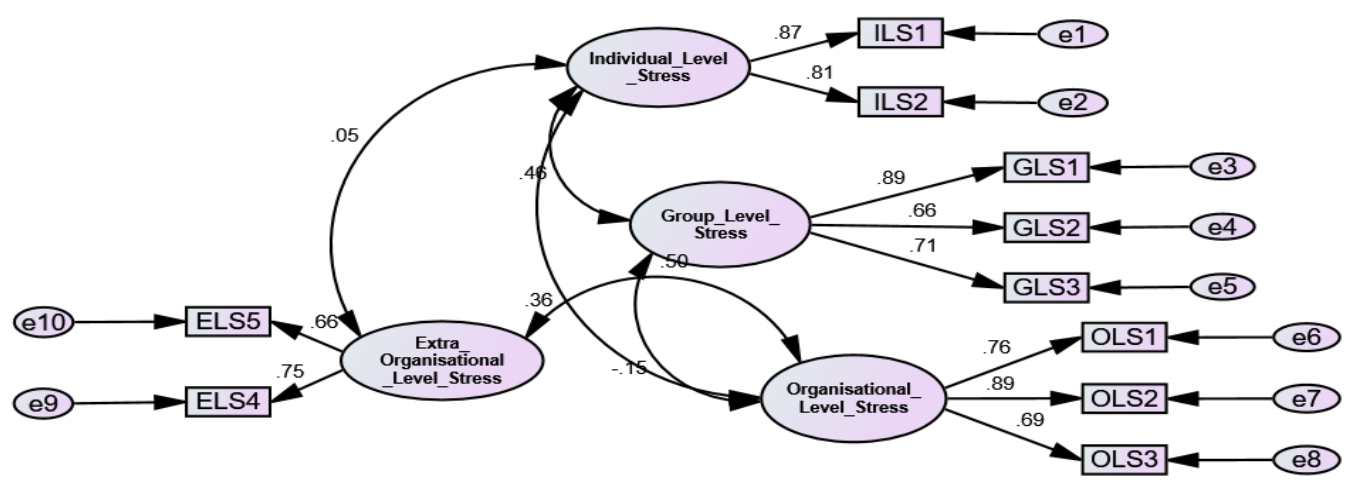

FOUR FACTOR CORRELATED CONFIRMATORY FACTOR ANALYSIS

CHI-SQUARE $=29.667 ; \mathrm{DF}=30 ; \mathrm{P} \_$VALUE $=.483 ; \mathrm{GFI}=.906 ; \mathrm{IFI}=1.000$

$\mathrm{TLI}=1.000 ; \mathrm{CFI}=1.000 ; \overline{R M S E A}=.000 ;$ SRMR $=.0570$

Figure 3. Confirmatory Factor Analysis (CFA)

Based on the goodness of fit parameters for observed constructs, results revealed a fitness of data to the hypothesized model. However, one of the indicators (ELS6) that was earlier retained during the EFA analysis, was removed or rejected in the CFA analysis above because 


\section{Macrothink}

it failed to meet the goodness fit criteria.

\subsection{Validity and Reliability Tests}

All retained indicators and constructs were tested for Construct Validity (CV) and composite reliability. The acceptable threshold is when Average Variance Explained (AVE > 0.5) and reliability $(\mathrm{CR}>0.7)$ as shown below:

Table 10. Construct Validity and Reliability

\begin{tabular}{|c|c|c|c|c|c|}
\hline Constructs & Indicators & $\begin{array}{l}\text { Factor } \\
\text { Loadings }\end{array}$ & $\begin{array}{l}\text { Factor Loadings } \\
\text { Squared }\end{array}$ & Validity & Reliability \\
\hline \multirow{2}{*}{$\begin{array}{l}\text { Individual Level } \\
\text { Stress (ILS) }\end{array}$} & ILS1 & 0.830 & 0.6889 & \multirow[t]{2}{*}{$\mathrm{AVE}=0.67>0.50$} & \multirow[t]{2}{*}{$\mathrm{CR}=0.80>0.7$} \\
\hline & ILS2 & 0.808 & 0.652864 & & \\
\hline \multirow{3}{*}{$\begin{array}{l}\text { Group Level } \\
\text { Stress (GLS) }\end{array}$} & GLS1 & 0.719 & 0.516961 & \multirow[t]{3}{*}{$\mathrm{AVE}=0.64>0.50$} & \multirow[t]{3}{*}{$\mathrm{CR}=0.84>0.7$} \\
\hline & GLS2 & 0.885 & 0.783225 & & \\
\hline & GLS3 & 0.805 & 0.648025 & & \\
\hline \multirow{3}{*}{$\begin{array}{l}\text { Organisational } \\
\text { Level Stress (OLS) }\end{array}$} & OLS1 & 0.678 & 0.459684 & \multirow[t]{3}{*}{$\mathrm{AVE}=0.61>0.50$} & \multirow[t]{3}{*}{$\mathrm{CR}=0.82>0.7$} \\
\hline & OLS2 & 0.888 & 0.788544 & & \\
\hline & OLS3 & 0.759 & 0.576081 & & \\
\hline \multirow{2}{*}{$\begin{array}{l}\text { Extra-Organisational } \\
\text { Level Stress (OLS) }\end{array}$} & ELS4 & 0.739 & 0.546121 & \multirow[t]{2}{*}{$\mathrm{AVE}=0.56>0.50$} & \multirow[t]{2}{*}{$\mathrm{CR}=0.72>0.7$} \\
\hline & ELS5 & 0.763 & 0.582169 & & \\
\hline \multirow{3}{*}{$\begin{array}{l}\text { Employee } \\
\text { Productivity (EPT) }\end{array}$} & EPT1 & 0.821 & 0.674041 & \multirow[t]{3}{*}{$\mathrm{AVE}=0.58>0.50$} & \multirow[t]{3}{*}{$\mathrm{CR}=0.80>0.7$} \\
\hline & EPT2 & 0.563 & 0.316969 & & \\
\hline & EPT5 & 0.871 & 0.758641 & & \\
\hline
\end{tabular}

Source: SPSS Output and Excel Calculations

\subsection{Structural Equation Model Development and Specifications}

Further analysis using the Structural Equation Model (SEM) was conducted in order to test the hypothesis developed in this study. The hypothesis for three predictors of employee performance (productivity) was tested using the specification of SEM and the results are shown in the diagram below;

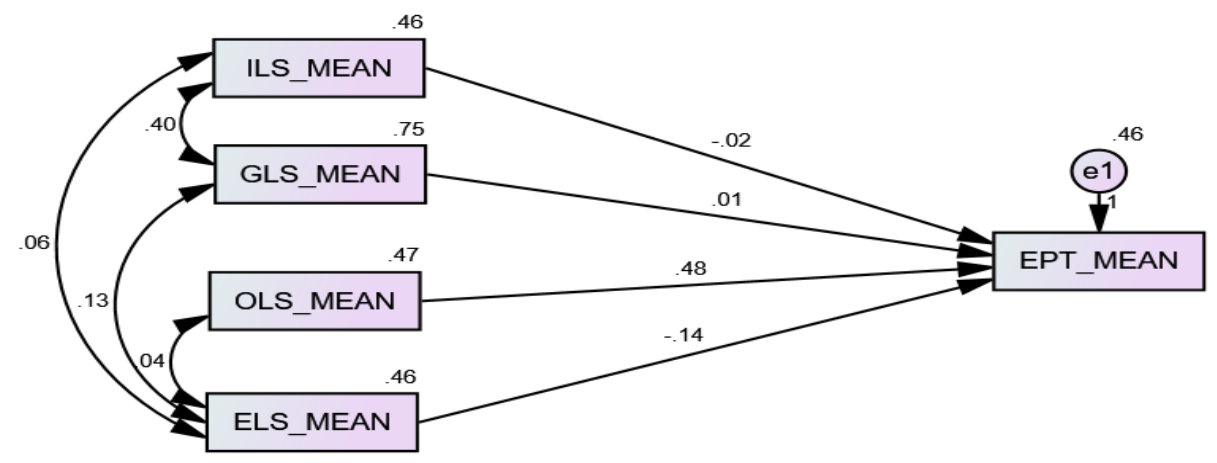

SEM WITH SPECIFICATIONS

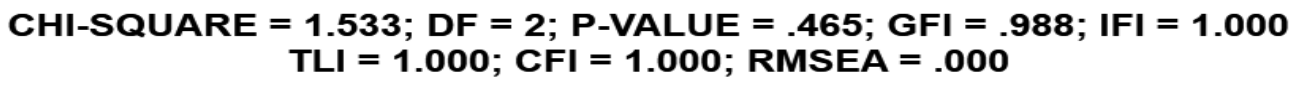

Figure 4. Structural Equation Model 


\section{Macrothink}

Table 11. Regression Weights: (Group number 1 - Default model)

\begin{tabular}{|l|l|l|l|l|l|l|l|}
\hline & & & Estimate & S.E. & C.R. & P & Label \\
\hline EPT_MEAN & $<---$ & ILS_MEAN & -.024 & .193 & -.127 & .899 & par_1 \\
\hline EPT_MEAN & $<---$ & GLS_MEAN & .005 & .155 & .035 & .972 & par_2 \\
\hline EPT_MEAN & $<---$ & OLS_MEAN & .480 & .144 & 3.330 & $* * *$ & par_3 \\
\hline EPT_MEAN & $<---$ & ELS_MEAN & -.142 & .147 & -.966 & .334 & par_4 \\
\hline
\end{tabular}

Although the specifications for goodness fit have been met as shown in figure 5 above, the following were observed as shown in table 32 above;

(i) At the $95 \%$ confidence interval (CI) using a sample of 50, there is no significant statistical evidence to suggest that individual level stress has a significant positive effect on employee performance in NFC bank. As a result, we decline to reject the null hypothesis.

(ii) At the $95 \%$ CI using a sample of 50, there is no significant statistical evidence to suggest that group level stress has a significant positive effect on employee performance in NFC bank. As a result, we also decline to reject the null hypothesis.

(iii) At the 95\% CI using a sample of 50, there is significant statistical evidence to suggest that organizational level stress has a significant positive effect on employee productivity in NFC bank. As a result, the null hypothesis is rejected.

(iv) At the $95 \%$ CI using a sample of 50, there is no significant statistical evidence to suggest that extra-organizational level stress has a significant positive effect on employee performance in NFC bank. As a result, we decline to reject the null hypothesis.

However, in order to improve on the analysis, a modified model with a mediation effect was created and tested for suitability using the specified parameters of SEM. The output of the model is shown below;

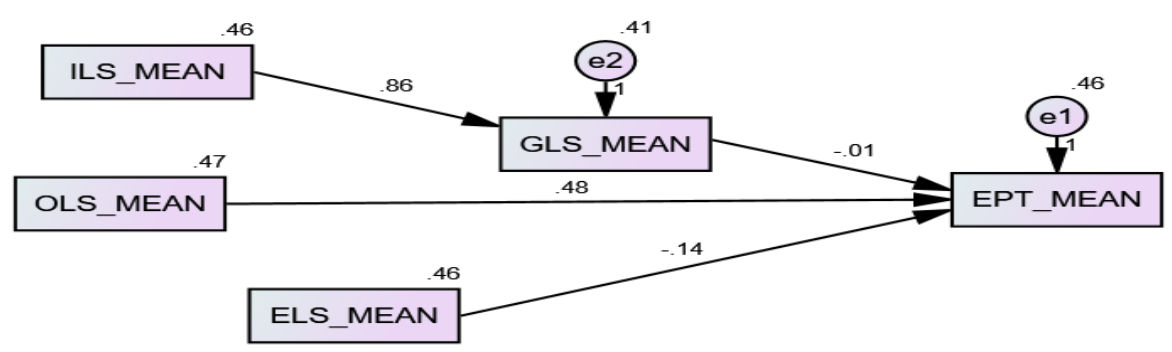

SEM WITH MEDIATION EFFECTS AND SPECIFICATIONS

CHI-SQUARE $=4.922 ;$ DF $=6$; P-VALUE $=.554 ;$ GFI $=.959 ;$ IFI $=1.000$

TLI = 1.000; CFI = 1.000; RMSEA = .000; SRMR =0.986

Figure 5. Modified model with a mediation effect 


\subsection{Modified Model with Mediation Effects}

The mediating effects of the modified model are explained below:

i. At the $95 \%$ CI using a sample of 50, there is no significant statistical evidence to suggest that group level stress has a significant positive effect on employee performance in NFC bank. As a result, we decline to reject the null hypothesis.

ii. At the $95 \%$ CI using a sample of 50, there is no significant statistical evidence to suggest that group level stress has a significant positive effect on employee performance in NFC bank. As a result, we decline to reject the null hypothesis.

iii. At the $95 \%$ CI using a sample of 50, there is significant statistical evidence to suggest that organizational stress has a significant positive effect on employee performance in NFC bank. As a result, the null hypothesis is thus rejected.

The results are shown in the table below;

Table 12. Regression Weights: (Group number 1 - Default model)

\begin{tabular}{|l|l|l|l|l|l|l|l|}
\hline & & & Estimate & S.E. & C.R. & P & Label \\
\hline GLS_MEAN & $<---$ & ILS_MEAN & .857 & .134 & 6.387 & $* * *$ & par_1 \\
\hline EPT_MEAN & $<---$ & GLS_MEAN & -.008 & .117 & -.065 & .948 & par_2 \\
\hline EPT_MEAN & $<---$ & OLS_MEAN & .480 & .144 & 3.329 & $* * *$ & par_3 \\
\hline EPT_MEAN & $<---$ & ELS_MEAN & -.142 & .147 & -.962 & .336 & par_4 \\
\hline
\end{tabular}

Analysis of the Indirect Effect of group level stress as a mediator:

At the $95 \%$ CI using a sample of 50, there is significant statistical evidence to suggest that group level stress has a significant positive mediating effect on the relationship between individual level stress and employee performance in NFC bank. Hence, the null hypothesis is thus rejected. 
Table 13. Harmonized Test of Hypotheses

\begin{tabular}{|c|c|c|}
\hline Hypotheses & $\begin{array}{l}\begin{array}{l}\text { P-Value at } \\
\text { Interval (CI) }\end{array} \\
\text { 95\% }\end{array}$ & Decision/conclusion \\
\hline $\begin{array}{l}\text { H1: Individual level stress has a significant effect } \\
\text { on the work performance of NFC Bank staff in } \\
\text { Cameroon }\end{array}$ & $\begin{array}{l}\text { P-Value }=0.899>0.05 \text { (statistically } \\
\text { insignificant) }\end{array}$ & $\begin{array}{l}\text { Decline to reject the } \\
\text { null hypothesis }\end{array}$ \\
\hline $\begin{array}{l}\text { H2: group level stress has a significant effect on } \\
\text { the work performance of NFC Bank staff in } \\
\text { Cameroon }\end{array}$ & $\begin{array}{l}\text { P-Value }=0.948>0.05 \text { (statistically } \\
\text { insignificant) }\end{array}$ & $\begin{array}{l}\text { Decline to reject the } \\
\text { null hypothesis }\end{array}$ \\
\hline $\begin{array}{l}\text { H3: Organisational level stress has a significant } \\
\text { effect on the work performance of NFC Bank } \\
\text { Staff. }\end{array}$ & $\begin{array}{l}\text { P-Value }=0.000<0.05 \text { (statistically } \\
\text { significant at } 1 \%, 5 \% \text { and } 10 \%)\end{array}$ & $\begin{array}{l}\text { Reject the null } \\
\text { hypothesis }\end{array}$ \\
\hline $\begin{array}{l}\text { H4: Extra-organizational level stress has a } \\
\text { significant effect on the performance of NFC } \\
\text { Bank Staff. }\end{array}$ & $\begin{array}{l}\text { P-Value }=0.336>0.05 \text { (statistically } \\
\text { insignificant) }\end{array}$ & $\begin{array}{l}\text { Decline to reject the } \\
\text { null hypothesis }\end{array}$ \\
\hline $\begin{array}{l}\text { H5:Group level Stress has a significant positive } \\
\text { mediating impact on the relationship between } \\
\text { Individual level stress and the work performance } \\
\text { of NFC Bank Staff }\end{array}$ & $\begin{array}{l}\mathrm{P}-\mathrm{V}=0.000<0.05 \quad \text { (statistically } \\
\text { significant at } 1 \%, 5 \% \text { and } 10 \%)\end{array}$ & $\begin{array}{l}\text { Reject the null } \\
\text { hypothesis }\end{array}$ \\
\hline
\end{tabular}

\section{Discussions and Conclusion}

This study was carried out with the objective of establishing the factors that causes work place stress, investigating the effect of stress on employees' performance and examining the effectiveness of stress management strategies at NFC Bank. Relevant models with respect to employee performance and stress were examined and a research problem was formulated. Available literature with respect to employee stress and its impact on employee performance was scrutinized. The results of this study show that organizational level stress and group level stress as a mediating variable between individual level stress and the work performance of NFC bank staff have a positive statistical significant effect on the performance of NFC bank staff. This can be seen in table 13 (harmonized test of hypotheses) where the $P_{-}$Value for the stated hypotheses are significant within a $99 \%$ confidence interval level. On the basis of the results obtained, it is concluded that stress has a significant effect on employee performance in NFC Bank and as a result has a negative effect on employees' performance and productivity. Therefore, it is strongly recommended that employers in the financial services sector should continually develop work stress management strategies such as developing a stress management policy in an attempt to reduce the high cost to the company associated with worker's stress.

\section{References}

Ahmed, A., \& Ramzan, M. (2013). Effects of Job Stress on Employees Job Performance: A Study on Banking Sector of Pakistan. IOSR Journal of Business and Management, 11(6), 61-68. https://doi.org/10.9790/487X-1166168

Akosso, V. N., Isoh, A. V. N., \& Grimbald, N. (2020). Modelling a Sustainable Human Capacity Development Framework of Selected Agro- Industrial Establishments in Cameroon. International Journal of Research in Commerce and Management Studies. 
https://doi.org/10.38193/IJRCMS.2020.2027

Atkinson, W. (2012). Stress: risk management's most serious challenge?. Risk Management, 5(1), 20-26.

Bickford, M. (2015). Stress in the workplace: A General Overview of the Causes, the Effects, and the Solutions. Canadian Mental Health Association. [Online] Available:

http://www.cmhanl.ca/pdf/Workplacestress.pdf

Bryman, A. (2012). Social research methods (4th ed.). Oxford university press.

Bryman, A., \& Bell, E. (2019). Business Research Methods (2nd ed.). Oxford University Press, Oxford.

Campbell, R. D., \& Austin, S. (2017). Effects of response time deadlines on adult's strategy choices for simple addition. Memory \& Cognition, 30(6), 988-994.

https://doi.org/10.3758/BF03195782

Clark, J. (2019). Stress: A management guide. London: Spiro Press. [Online] Available: http://cmhanl.ca/education/publications/cwtms/index.php

Cohen, L. et al (2005). Research Methods in Education (5th ed.). Great Britain.

Cohen, L., Manion, L., \& Morrison, K. (2007).Research methods in education (6th ed.). London: Routledge. https://doi.org/10.4324/9780203029053

Cooper, C. L., \& Palmer, S. (2008). Conquer your stress. Institute of Personnel and Development, 4(8), 10-18.

Creswell, J. W. (2012). Qualitative inquiry and researech design: Choosing among five approaches (3rd ed.). Lincoln, NB: Sage Publications.

Crotty, M. (2008). The foundations of social research: Meaning and perspective in the research process. Sage Publications.

Devi, N. (2012). Effects of Work Stress on Job Performance. International Indexed \& Referrel. Research Journal, 3(35). [Online] Available:

http://cmhanl.ca/education/publications /cwtms/index.php

Dyck, D. (2015). The toxic workplace. Benefits Canada, 52.

Elovainio, M., Kivimaki, M., \&Vahtera, J. (2017). Organizational Justice: Evidence of a New.

Greenberg, J. S. (2019). Comprehensive stress management (6th ed.). New York: WCB/McGraw-Hill.

Guba, E. G., \& Lincoln, Y. S. (2004).Competing paradigms in qualitative research. Handbook of qualitative research, 2, 163-194.

Horwitz, L., Ellen J. M. A., Melinda, S. M. A., \& Roberts, S. M. A. (2020). How to reduce and manage job and workplace stress. [Online] Available:http://www.helpguide.org 


\section{Macrothink}

Business and Economic Research ISSN 2162-4860 2021, Vol. 11, No. 1

Jones, F., \& Bright, J. (2011). Stress: Myth. Theory and research. [Online] Available: http://www.helpguide.org

Katz, L., \& Epstein, S. (2010). Constructive thinking and coping with laboratory induced stress. Journal of Occupational Health Psychology, 3, 322-355.

Keinan, G. (2007). Decision making under stress: Scanning of alternatives under controllable and uncontrollable threats. Journal of Personality and Social Psychology, 52, 639-644. https://doi.org/10.1037/0022-3514.52.3.639

Krietner and Kinicki. (2008). Organizational Behaviour 8th Edition, McGraw Hill Publishing, New York.

McGrath, J. E. (2016). Stress and behaviour in organizations. In M. D. Dunnette (Ed.), handbook of industrial and organizational psychology (pp. 1351-1395). Chicago McNally.

Mills, H. (2019). Stress in the Workplace. [Online] Available:

https://www.mindtools.com/cgi-bin/sgx2/shop.cgi?page=StressMTC Downloads1.html.

Organizational Commitment and Managing it. International Journal of Business and Management Research, 3(1), 15-21. [Online] Available: http://www.vsrdjournals.com

Raitano, R. E., \& Kleiner, B. H. (2004). Stress management: stressors, diagnosis, and preventative measures. Management Research News, 27(4/5), 32-38.

https://doi.org/10.1108/01409170410784446

Robbins, S. (2016). Organizational Behavior (11th ed.). India: Dorling Kindersley Publishing.

Saunders, M., Lewis, P., \& Thornhill, A. (2009). Research methods for business students. Prentice Hall .

Smith, J. C. (2020). Stress Management: A comprehensive handbook of techniques and strategies. New York: Springer.

Trivette, P. S. (2013). A national survey of occupational stress, psychological strain and coping resources in elementary school counsellors. Doctoral dissertation, Virginia Polytechnic Institute and State University.

Van Galen, G. P., \& Van Huygevoort, M. (2000). Error, stress and the role of neuromotor noise in space oriented behaviour. Biological Psychology, 51, 151-171.

https://doi.org/10.1016/S0301-0511(99)00037-X

Wallace, J. E. (2003). Research on Job Stress, Depression and Work to Family Conflict. Department of Sociology, University of Calgary, Canada.

Wickens, C. D., \& Dixon, S. R. (2017). Pilot control of multiple-UAVs: Predicting performance through operator workload and task interference models.

Williams, C. (2011). Research methods. Journal of Business \& Economics Research (JBER), 5(3). https://doi.org/10.19030/jber.v5i3.2532 


\section{Macrothink}

Business and Economic Research

ISSN 2162-4860 2021, Vol. 11, No. 1

Zainudin, A. (2015). SEM made simple: A gentle approach to learning structural equation modeling. MPWS Rich Publication Sdn. Bhd.

Zikmund, W. (2003). Business Research Methods (7th ed.). Thomson/ South-Western.

\section{Copyright Disclaimer}

Copyright for this article is retained by the author(s), with first publication rights granted to the journal.

This is an open-access article distributed under the terms and conditions of the Creative Commons Attribution license (http://creativecommons.org/licenses/by/4.0/). 